\title{
IAMJ
}

INTERNATIONAL

AYURVEDIC

MEDICAL JOURNAL

[]요

\section{A REVIEW ON ROLE OF KSHARAGAD IN ALLERGIC SKIN DISEASES W.S.R. TO DUSHIVISHA JANYA TWAK VIKAR}

\author{
Rashmi Choudhary ${ }^{1}$, Prabhat Patel $^{2}$, S. R Inchulkar ${ }^{3}$, Aruna Ojha ${ }^{4}$ \\ ${ }^{1,2}$ M.D. Scholar, ${ }^{3}$ Professor, ${ }^{4}$ Reader \\ ${ }^{1,3}$ Post Graduate Department of Agad Tantra Evam Vidhi Vaidyak, Govt. Ayurved College, Raipur, \\ Chhattisgarh, India \\ ${ }^{2}$ P.G Department of Samhita Siddhant, Govt. Ayurved College, Raipur, Chhattisgarh, India \\ ${ }^{4}$ P.G Department of Kaya Chikitsa, Govt. Ayurved College, Raipur, Chhattisgarh, India
}

Corresponding Author: choudharyrashi98@gmail.com

https://doi.org/10.46607/iamj1908112020

(Published online: November 2020)

Open Access

(C) International Ayurvedic Medical Journal, India 2020

Article Received: 17/10/2020 - Peer Reviewed: 09/11/2020 - Accepted for Publication: 16/11/2020

(D) Check for updates

\begin{abstract}
Dushivisha is an important concept in Vishatantra. It is a low potent poison which gets vitiates due to dushit Desh, Kala, Anna and Diwaswapna which are similar to the factors like industrialization, seasonal variation, synthetic food items, changing lifestyle. Now a day's due to this lifestyle of a modern man, immune system of a person declines and leads to evolution of various diseases out of which allergic skin diseases are common. Dushivisha is a peculiar poison which vitiates Dhatus. In its relation with Rakta Dhatu some of the skin problems caused by Dushivisha which are described in Samhitas are Kustha, Visarpa, Bhinna Varna, Shonitdusti, Shitapitta, Udar$d a$, Kotha. These symptoms are similar as that of hypersensitivity reactions. Udarda-Sheetapitta-Kotha has almost similar symptomatology and causative factors as Urticaria. Asatmya, Virudhahara and Dushivisha are common etiological factors for these diseases which can be correlated with allergic conditions. So, various types of allergic skin diseases can be taken under Dushivisha Janya Twak Vikar (Shitapitta-Udarda-Kotha). Urticaria affects $20 \%$ of people at some or the other time in their life. So, on looking at the increased incidence rate of allergic skin diseases, it's a need to find some conservative source which would be helpful in management of skin diseases from the root by cleansing vitiated Dhosha and balancing whole body. Ksharagad mentioned in Charak Samhita is one of those formulations helpful to prevent such diseases by its actions like Kusthgna, Krimghna, Shothhar, Kandughna, Twachya, Tridoshahar properties, increasing immunity and suppressing allergic activity.
\end{abstract}


Keyword: Dushivisha, Allergy, Viruddha, Immune, Ksharagad.

\section{INTRODUCTION}

A poison, which is having fewer properties, which means less than ten classical properties that actually a poison should have, or either the poison which is having lesser potency of all the ten properties, attains a latent or hidden stage in the body is called Dushi Visha (latent poison). Sage Sushruta described Dooshivisha as any kind of poison originating from inanimate or animate sources or any artificial poison (Kritrima visha) retained in the body after partial expulsion or which has provisionally undergone detoxification, by anti-poisonous drugs, forest fire, the wind or the sun is termed Latent poison (Dooshivisha) ${ }^{1}$. Low potency of all the ten qualities are said to be responsible for the delayed action and cumulative toxicity on the body ${ }^{2}$. Now a day each and everything like food, water, air, soil, milk, etc. are polluted through toxic substances. For e.g. Synthetic hormones are in the milk, meat and other dairy product we eat. Pesticides, herbicides and fungicides are also present in grains and vegetables. These toxins enter into our body by different routes. They enter the system through blood circulation, and retention of these toxins results Toxaemia which slowly affect our vital system and immune system and can cause various diseases. In Ayurveda, allergic manifestation is mentioned under the concept of Satmyaasatmya. It manifests due to exposure to Asatmya ahara-vihara and contact with different poisonous materials (allergens) ${ }^{3}$. Unwholesome diet, excess liquid diet and excess guru diet leads to Mandagni (reduced digestive power) which in turn leads to formation of Ama. Ama is considered as a group of intermediary metabolites producing oxidative stress to the body tissues which is involved in the pathogenesis of many dermatological disorders ${ }^{4}$. The antigen-antibody mediated abnormal immune response can be correlated with the pathological and clinical feature of 'dhatugata visha' or "dooshivisha' in Ayurveda. Some of the skin problems caused by Dushivisha which are described in Samhitas are Kustha, Visarpa, Bhinna Varna, Shonitdusti, Shitapitta, Udarda, Kotha. Symptoms of allergic skin reaction is mentioned as Kotha in Brihata Trayi later on it is developed as separate disease under the title Sheetapitta-Udarda-Kotha by Madhavakara ${ }^{5}$. Udarda-Sheetapitta-Kotha has almost similar symptomatology and causative factors as Urticaria characterized by erythematous and pruritic rashes, burning sensation on skin ${ }^{6}$. Though the disease is not life threatening, it makes patient worried, due to its appearance and severe pruritus. In some cases, the disorder is relatively placid but recurrent and frustrating for both patient and physician.

These diseases can be prevented and if it occurs then can be cured through Ayurvedic Agada's. Agada's are the counter measures taken against the manifestation caused by poisoning. So, Ksharagad ${ }^{7}$ is selected which can provide very good result in symptoms of Itching, redness, shotha (inflammation), wheal formation, shonit dustilakshan etc. by improving immunity and its actions like Kusthghna, Krimghna, Shothhar, Kandughna, Twachya, Tridoshahar It also contain palash kshara. And Kshar has been seemed to be superior to Shastras and Anushastras because of its actions such as Chedana, Lekhana and alleviation of Tridhosha. Kshara is that which does Lekhana of Tvak, Mamsadi and removes the vitiated Doshas ${ }^{[8]}$. Thus, it can be helpful in management of various allergic skin diseases.

\section{Aim and Objectives}

- To elaborate the concept of Dushivisha mentioned in various Samhitas.

To give a review on the effect of Ksharagad helpful in management of Dushivisha janya twak vikar 
Table 1: General Clinical features of Dushivisha as per various acharya' ${ }^{9-15}$

\begin{tabular}{|c|c|c|c|c|c|c|c|c|}
\hline Sr. & Feature & Shusrut & Charak & $\begin{array}{l}\text { Astang } \\
\text { Sangrah }\end{array}$ & $\begin{array}{l}\text { Astang } \\
\text { Hridaya }\end{array}$ & $\begin{array}{l}\text { Yogratn- } \\
\text { akar }\end{array}$ & $\begin{array}{l}\text { Bhaopr- } \\
\text { akash }\end{array}$ & $\begin{array}{l}\text { Madhav } \\
\text { nidan }\end{array}$ \\
\hline 1. & Annamada(Inbrient after food) & $\checkmark$ & - & - & - & $\checkmark$ & $\checkmark$ & $\checkmark$ \\
\hline 2. & Avipaka(Indigestion) & $\checkmark$ & - & - & - & $\checkmark$ & $\checkmark$ & $\checkmark$ \\
\hline 3. & Arochak(Loss of Taste) & $\checkmark$ & - & - & - & $\checkmark$ & $\checkmark$ & $\checkmark$ \\
\hline 4. & $\begin{array}{l}\text { Mandal-Kotha(Patches \&Rashes on } \\
\text { Skin) }\end{array}$ & $\checkmark$ & $\checkmark$ & $\checkmark$ & $\checkmark$ & $\checkmark$ & $\checkmark$ & $\checkmark$ \\
\hline 5. & Moha(Delusion) & $\checkmark$ & - & - & - & $\checkmark$ & $\checkmark$ & $\checkmark$ \\
\hline 6. & Dhatukshaya(Wasting of Tissue) & $\checkmark$ & - & - & - & $\checkmark$ & $\checkmark$ & $\checkmark$ \\
\hline 7. & $\begin{array}{l}\text { Pada-Karasya } \\
\text { Shoph(Edema of Feet \& Hand }\end{array}$ & $\checkmark$ & - & - & - & $\checkmark$ & $\checkmark$ & $\checkmark$ \\
\hline 8. & Dusyodar(Ascities) & $\checkmark$ & - & $\checkmark$ & $\checkmark$ & $\checkmark$ & $\checkmark$ & $\checkmark$ \\
\hline 9. & Murcha(Unconsiousness & $\checkmark$ & - & $\checkmark$ & $\checkmark$ & $\checkmark$ & $\checkmark$ & $\checkmark$ \\
\hline 10. & Visham jwar(fever) & $\checkmark$ & - & - & - & $\checkmark$ & $\checkmark$ & $\checkmark$ \\
\hline 11. & Trishna(Profound Thirst) & $\checkmark$ & - & $\checkmark$ & $\checkmark$ & $\checkmark$ & $\checkmark$ & $\checkmark$ \\
\hline 12. & Unmaad(Insanity) & $\checkmark$ & - & - & - & $\checkmark$ & $\checkmark$ & $\checkmark$ \\
\hline 13. & Anaha(Flatulence) & $\checkmark$ & - & - & - & $\checkmark$ & $\checkmark$ & $\checkmark$ \\
\hline 14. & $\begin{array}{l}\text { Shukrakshaya(Asperma- togene- } \\
\text { sis/oligospermia) }\end{array}$ & $\checkmark$ & - & - & - & $\checkmark$ & $\checkmark$ & $\checkmark$ \\
\hline 15. & Chhardi(Vomiting) & $\checkmark$ & - & $\checkmark$ & $\checkmark$ & $\checkmark$ & $\checkmark$ & $\checkmark$ \\
\hline 16. & Atisar(Loose motion) & $\checkmark$ & - & $\checkmark$ & $\checkmark$ & $\checkmark$ & $\checkmark$ & $\checkmark$ \\
\hline 17. & Vaivarnya(Discoloration of body) & $\checkmark$ & - & $\checkmark$ & $\checkmark$ & $\checkmark$ & $\checkmark$ & $\checkmark$ \\
\hline 18. & Swarvikara(Stammering Speech) & $\checkmark$ & - & $\checkmark$ & $\checkmark$ & $\checkmark$ & $\checkmark$ & $\checkmark$ \\
\hline 19. & $\begin{array}{l}\text { Vaigandha much (Bad smell of } \\
\text { mouth) }\end{array}$ & $\checkmark$ & - & - & - & $\checkmark$ & $\checkmark$ & $\checkmark$ \\
\hline 20. & $\begin{array}{l}\text { Vairasya much (Bad Taste of } \\
\text { mouth) }\end{array}$ & $\checkmark$ & - & - & - & $\checkmark$ & $\checkmark$ & $\checkmark$ \\
\hline 21. & Bhram(Giddiness) & $\checkmark$ & - & - & - & $\checkmark$ & $\checkmark$ & $\checkmark$ \\
\hline 22. & Vicheshta(Abnormal Activity) & $\checkmark$ & - & - & - & $\checkmark$ & $\checkmark$ & $\checkmark$ \\
\hline 23. & Shwas(Dysnoea) & $\checkmark$ & - & - & - & $\checkmark$ & $\checkmark$ & $\checkmark$ \\
\hline
\end{tabular}




\section{Samprapti (Pathogenesis) ${ }^{16-17}$}

Samprapti of allergic skin diseases has not mentioned in text but it can be correlated with Dushi Visha Samprapti which is explained in below -

Nidan sevan (Aggravating factors) $\longrightarrow$ Aggravating of Dosha (humors)<smiles>[CH]</smiles>

Vitiation of Dhatu (elements of body) specially Rakta Dhatu<smiles>[CH]=C</smiles>

Visha can be Sthavar (plant origin), Jangam (animal origin), or Kritrima (Artificial)<smiles>C1=C[As]=C1</smiles>

If not expelled out properly or suppressed by Environmental factors

Deposit into the body tissues having mild potency in Nature, enveloped by

గl

(Urticaria), Kitibha etc.

\section{Correlation of Dushivisha and Allergy}

In Ayurvedic literature the prime factors taking part in pathogenesis of Sheetapitta-Udarda-Kotha (urticaria) involves dushivisha, dushitrakta, ama uttpatti. The unwholesome substances are antagonists to the body tissues so they can be considered as antigens, which react with the antibody (dhatus). Whenever an unwholesome substance enters the body and reaches to bloodstream, the resistance and the immune system start acting on them. This unwholesome food leads to Jathragnimandhya and Dhatvagnimandhya so there is a formation of Apakva substance, which is called 'Aama'. Apakva substance which is produced by defective metabolism circulates in the entire body as Amavish which can be correlated to histamine. In modern science, release of histamine from the mast cell is the ultimate cause of Urticaria. Also due to this unwholesome substance cytokines get activated and produce immunoglobins which in healthy individuals neutralize the antigens. But in unhealthy person or person involved in pragyapradha or whoever individual whose immune power is weak, cytokines instead of neutralizing antigens produces IgE. The IgE gets sensitized and binds to the mast cells and basophils. They act as mild toxins or in other words as a Dushivisha, they remain latent till the next exposure to the antigen (unwholesome). The aggravating factors like dushit annna, kala, pragvayu helps in degranulation of mast cells and the remission occurs. In Sheetpitta there is already Rasadhatu dushti, Rasavaha Srotodushti and Tvakasthan Khavaigunya because of Agnimandhya. So, whenever body comes to the contact with harmful substances, Samprapti of Sheetpitta immediately takes place and generates the symptoms.

\section{Dushi visha chikitsa ${ }^{18}$}

According to Ashtang Hridaya Uttarsthan the patient suffering from dushi visha (cumulative toxins) is firstly given swedana (Sudation) as a purvakarma (Pre procedure) then vaman (emesis), virechana (purgatives) as pradhan karma (Main procedure) then is given with madhu (honey).

\section{Ksharagad Contents ${ }^{19-24}$}

\begin{tabular}{|l|l|l|l|l|l|}
\hline Sr. No. & Drug & Rasa (Taste) & Virya (potency) & Vipaka & Karma (Action) \\
\hline 1. & Haridra (Curcuma longa) & Tikta, Katu & Ushna & Katu & Shotha, Sheetapitta \\
\hline 2. & Surasmanjari(Ocimum sanctum) & Tikta, Kashaya & Ushna & Katu & Twakdosha, Shotha \\
\hline 3. & Daru haridra (Berberis aristata) & Tikta, Kashaya & Ushna & Katu & Twakdosha, Shotha \\
\hline
\end{tabular}




\begin{tabular}{|c|c|c|c|c|c|}
\hline 4. & $\begin{array}{l}\text { Jatamamsi (Nardostachys } \\
\text { jatamansi) }\end{array}$ & Tikta, Kshaya & Sheeta & Katu & Kushthaghna, Twagvikara \\
\hline 5. & Harenu (Vitex negundo) & Tikta, Katu & Ushna & Katu & Shothaghna, Anulomak \\
\hline 6. & Hingu (Ferula northax) & Katu & Ushna & Katu & Agnimandya, Kandughna \\
\hline 7. & Sariva (Hemidusmus indicus) & Tikta, Madhura & Sheeta & Madhura & Vishaghna,, Dahaprashman \\
\hline 8. & Madhuka (Glycyrrhiza glabra) & Madhura & Sheeta & Madhura & Charmaroga, Kandu, Visha \\
\hline 9. & Shunti (Zingiber officinale) & Katu & Ushna & Madhur & $\begin{array}{l}\text { Sheetapittahar, Agniman- } \\
\text { dya, Shothahar }\end{array}$ \\
\hline 10. & Pippali (Piper longum) & Katu & $\begin{array}{l}\text { Anu- } \\
\text { ushansheet }\end{array}$ & Madhur & $\begin{array}{l}\text { Raktashodhak, Shoolprash- } \\
\text { man }\end{array}$ \\
\hline 11. & Maricha (Piper nigrum) & Katu & Ushna & Katu & Kushthaghna,, Twagvikara \\
\hline 12. & Palasha (Butea monosperma) & $\begin{array}{l}\text { Tikta, } \quad \text { Katu, } \\
\text { Kashaya }\end{array}$ & Ushna & Katu & Charmaroga, Vishaghna \\
\hline 13. & Kushta (Saussurea lappa) & Tikta & Ushna & Katu & $\begin{array}{l}\text { Vishaghna, } \\
\text { Twakroga }\end{array}$ \\
\hline 14. & Laksha (Laccifer lacca) & Kashaya & Sheet & Katu & Krimighna, Twakdoshhar \\
\hline 15. & Gairik (Red ochre) & $\begin{array}{l}\text { Madhura, } \\
\text { Kashaya }\end{array}$ & Sheet & Katu & Vishaghna \\
\hline 16. & Saindhav lavan (Rock salt) & & Sheet & & Tridoshashamak, Deepan \\
\hline
\end{tabular}

\section{Probable Mode of Action of Kshragad Vati:}

In present study management of Allergic skin diseases (Sheetapitta-Udarda-Kotha) can be done with Ksharagad vati. As rightly said by all Acharyas, some drugs may act through rasa, some through Guna or Veerya, vipaka or prabhava or it may be the combined effect of all the ingredients. Hence, to understand the mode of Action of medicines, it is necessary to understand the Pharmacodynamics by understanding dominant Rasa, Guna Virya and Vipaka.

Rasa: Mostly drugs of ksharagad are having katu,tikta, kasya and madhur rasa. Katu rasa possesses properties like Vishaghna, Kandughna, Vranaprasadana, shothahar, krimighna, kleda shoshan, deepan, pachan, lekhan, widens tissue pore, mitigates kapha, udardaprashman. Tikta rasa has the property of Raktaprasadana, krimighna, Vishaghna, Kushthaghna, Kandughna, dahaprashamana, skin diseases, kapha shoshan, deepan, pachan, shrotoshodhan. While kasaya rasa has properties like lekhan, kleda shoshan it also restores normal color of skin and mitigates kapha, pitta and rakta. Madura rasa has vishghna, pitta-vata shamak properties and maintains healthy skin. According to Samprapti of Sheetpitta, Sheetpitta is VataKapha pradhan Tridoshaja Vyadhi. Ksharagad con- tains drugs having Vatakaphaghna and Tridoshara property. Kapha Dosha is subsided by Katu, Tikta and Kashaya Rasa. Madura rasa has pitta-vata shamak properties. $^{25-26}$

Guna: Mostly drugs of ksharagad are having laghu, ruksha, snigdha, tikshna guna. Laghu guna possess kaphashamaka property. By its Srotoshodhaka and agnidipan property it acts on minute channels and removes the Amavisha. Acharya Sushruta in Sutrasthan 46 has described lekhana and Ropana properties of Laghu guna. Lekhana property might help to expel the sticked toxins by scrapping. Acharya Hemadri has given Shoshana property of Ruksha guna. It also has kaphashamak property. Acharya Hemadri has described Shodhana property of Tikshna guna. Acharya Madhava has described Kaphavatahara and Lekhana property of Tikshna Guna. Snigdha guna pacifies vatta, dhatu and varna vardhak. Guna like Laghu, Ruksha Tikshna have Kaphahara property. ${ }^{27}$

Veerya: Mostly drugs of ksharagad are having ushna veerya and some have sheeta veerya. According to Ashtang Sangrah Sutrasthan chapter 17, Ushna veerya has Vatakaphashamaka and Pachak property. According to Ashtang Hridaya Sutrasthan chapter 9 it has Ashupaka property through which it acts quickly at 
minute channels. Sheet veerya shows pitta shamak, raktaprasadan properties. Sheeta veerya drugs are capable of antagonizing the adverse effect of Visha. ${ }^{28}$

Vipaka: Vipaka like Katu has also Kaphahar property. Madhur vipaka vata pitta shamak hence shows tridoshahar action. ${ }^{29}$

Karma: Looking to the karmas, it is clear that the drugs are having Kushthaghna, Kandughna, krimighna, shothshar, shoolprashman, dahaprashman, vedanashapan, twakdoshahara, raktashodhak karma which clearly explain its mode of action in Allergic skin diseases. In Allergy, Jatharagnimandhya and Dhatvagnimandhya are involved and also Ama rasa. Maximum drugs are having Deepana, Pachana, Anulomana properties which corrects this condition of $\mathrm{Ag}$ nimandya \& stops the production of Aamavisha. Karma like Deepana, Pachana, Rochana and Rasayana corrects Agni and are having definite effect on Srotasa that produces proper Rasa Dhatu which ultimately correct Kapha as it is Aasharaya of Rasa Dhatu. Hence, breaks pathology and corrects pathophysiology of allergy. Raktashodhaka property corrects the vitiated Raktadhatu and helps in maintaining normal functions of Rakta Dhatu. Vishaghna property helps in detoxifying the Dushi Visha, which is having Alpaveerya and is deep seated in Raktadhatu. Thus, prevents allergic skin diseases. Prabhao/ Roghaghnata: Ksharagad works on agnimandya, amadoshahara, immunostimulatory, shotha, daha, twakvikaar, vishavikar, inflammation, shool, krimi, deepan, pachan, burning sensation, raktavikar. Adaraka and Harida shows direct effect towards Allergy. Being a combination of drugs bearing similar qualities a synergistic drug action can be assumed. Due to the above-mentioned properties Kshargada is Tridoshahara, Twakdoshahara, Antitoxic and Rakthasodhaka.

\section{DISCUSSION}

Present food habits, lifestyle and mental attitudes etc. are entirely different from that of the past. The basic essentials of life air, food and water are all polluted and the hazards paint a gloomy picture for the coming generation. The toxicity is nothing but the degree which a substance can harm human beings or animals. Hence, while treating any skin disease we have to think of Dushivisha also. In Ayurveda, Ksharagad is one of the agads having contents that possess properties like Varnya (Good for skin colour), Kapha-Pitta Shamak, Shothahar (Reduce swelling), Kushthaghna (Beneficial in skin disease), Vranropak (Wound healing), Raktashodhak (Blood purifier), Vedanasthapak (Reduce pain), Kandughna (Reduce itching) and Dahaprashaman (Reduce burning), vishaghna, krimighna, shoolprashman which mostly act on twakroga. This preparation is very useful as they are having Deepan, Pachan properties, reduces the Kleda, which is helpful in pacifying the symptoms like Kandu and Daha of urticaria and also agnideepan property helps to pacify ama. As, Prakupita Vata and Kapha when being mixed with Pitta spreads internally and externally resulted into Sheetapitta-Udarda-Kotha. Ushna, Tiksha, Ama Pachak and Vatanuloman properties are excellent for Vata Kapha Shaman and Vimargagami Pitta treatment. Marich is said to be drug of choice for Urticaria. While other's having Rasayana, Antibacterial, antiinflammatory, Antioxidant, immunostimulatory, antianxiety property helps to deal with allergic skin diseases and also acts on symptoms like ajeerna, hrillas, aruchi. So, Ksharagad is useful to treat allergic skin disorders caused by dushivisha.

\section{CONCLUSION}

From above discussion we can conclude that as per Ayurveda various conditions like Asatmyaahara, Virudhahara and Dushivisha are common etiological factors for these diseases which can be correlated with allergic conditions. Dushivisha shows various types of toxic symptoms and disorders in different systems of body including skin. Udarda-Sheetapitta-Kotha has almost similar symptomatology and causative factors as Urticaria. In modern science there is vast treatment of Urticaria and other allergic skin disorders, but reoccurrence of disease is common in many cases. Ayurve$d a$ has lot of potential in the treatment aspect of allergic skin reaction by using of various Ayurvedic formulations and by following Pathya apathya in a logical manner. So, here was the review to highlight on the effects of toxins on human body and challenges to- 
wards the society and preventive as well as management regarding these toxic effects.

\section{REFERENCES}

1. Murthy KRS Ed., Susruta Samhita, Kalpasthana 2/2533. Reprint, Varanasi; Chaukhamba Orientalia, 2012, 423-424.

2. Bhide Bhargav, Acharya Rabinarayan. Concept Of Visha And Its Pharmacological Basis In Ayurveda. IJRAP 2012; 3(2):137-140

3. Charak Samhita - Hindi Translation by Brhamananda Tripathi, Chaukhambha Bharati Academy Varanasi2007, Sutrasthana Chapter 26, Verse 81, Pp. 492.

4. Saini Neera, Byadgi PS. Clinical and Scientific Evaluation Of Ama In Amavata. Int. J. Res. Pharma 2014; 5(5):587-593.

5. Madhava Nidana - Hindi Translation by Narendranath Shastri, Motilal Banarasidas Pratisthana, Delhi, Chapter 57, Pp. 638.

6. Harrison's Principles of Internal Medicine, Editors Brian L. Casper \& Oters - 19th Edition, Publishers Mcgraw Hill Education, Pg 2117

7. Acharya Charak - Charak Samhita Of Agnivesha By Chakrapani Edited By Vaidya Yadavji Trikamji Acharya, Published By Chaukhamba Surbharti Prakashan, Varanasi $2012 \mathrm{Pg} 753$.

8. Maharshi Sushruta, Sushrut Samhita Of Ambikadatta Shastri, Chaukamba Sanskrit Samsthan, Varanasi, Edition 2010(Sh.Su.11/3)

9. Maharshi Sushruta, Sushrut Samhita Of Ambikadatta Shastri, Chaukamba Sanskrit Samsthan, Varanasi, Edition 2010, (Su.Kalp.2/27-32)

10. Maharshi Sushruta, Sushrut Samhita Of Ambikadatta Shastri, Chaukamba Sanskrit Samsthan, Varanasi, Edition 2010, (Su.Su.2/30-32

11. Vriddha Vagbhata, Ashtanga Samgraha With Commentary By Prof. K. R. Srikantha Murthy, Chowkhamba Orientalia 2005, (A.S.Ut.40)

12. Vagbhatta, Ashtanga Hridaya By Bramhanand Tripathy, Chowkhamba Sanskrit Orientalia, Delhi Reprint Edition 2012, (A.H.Ut.35/34-36)

13. Yogratnakar Of Vidyotini Hindi Commentary Edited By Vaidya Shri Laxmipati Shastri, Chowkhamba Surbharti Prakashan, Varanasi, 2013, Chap. Visha Nidan, Pg 463.

14. Bhavamishra, Bhavaprakash Nighantu, Hindi Translation By Krishna Chandra Chunekar, Chowkhamba Vishvabharti, Varanasi Reprint Edition 2015, Vol 2 Chapter 67, Madhyam Khanda,pg 679-80.

15. Shri Madhavkara, Madhav Nidan, By Sudarshan Shastri, Vidyotini Hindi Commentary, Chaukhambha Prakashan, Varanasi, Edition Reprint 2009, Vol 2, (M.Ni.69), pg 237

16. PV Sharma, English commentary, Sushrut samhita, Edition chaukhamba Visvabharti Oriental publisher, Varanasi- 2010, 3, Kalp sthan (2/29)
17. PV Sharma, Charaka samhita, Edition chaukhamba Orientalia, Varanasi- 2008, 4, Chikitsa sthanam (23/31)

18. Dr. Bramhanand Tripathi Editor, Ashtanghrudayam of Shrimadvagbhata edited with 'Nirmala Hindi Commentary, Chaukhamba Sanskrit pratishthan, Delhi, Reprint 2014, Uttarsthana; Vishapratishediyadhyaya, chapter 35, verse 38 ,

19. C.C.R.A.S. Dept. of Ayush, ministry of health and family welfare, govt. of India data base on medicinal plants Vol -1 2000 pg 152,120,394,336

20. C.C.R.A.S. Dept. of Ayush, ministry of health and family welfare, govt. of India data base on medicinal plants Vol -2 2005 pg 500.

21. C.C.R.A.S. Dept. of Ayush, ministry of health and family welfare, govt. of India data base on medicinal plants Vol -3 2005 pg 561, 472.

22. C.C.R.A.S. Dept. of Ayush, ministry of health and family welfare, govt. of India data base on medicinal plants Vol 52002 pg 315,187,164.

23. C.C.R.A.S. Dept. of Ayush, ministry of health and family welfare, govt. of India data base on medicinal plants Vol 82008 pg 125.

24. C.C.R.A.S. Dept. of Ayush, ministry of health and family welfare, govt. of India data base on medicinal plants Vol 7 pg 135,179.

25. Charak Samhita - Hindi Translation by Brhamananda Tripathi, Chaukhambha Bharati Academy Varanasi2007, Sutrasthana Chapter 26, verse 43.

26. Maharshi Sushruta, Sushrut Samhita Of Ambikadatta Shastri, Chaukamba Sanskrit Samsthan, Varanasi, Edition 2010(Sh.Su.42/16)

27. Bhavamishra, Bhavaprakash Nighantu, Hindi Translation By Krishna Chandra Chunekar, Chowkhamba Vishvabharti, Varanasi Reprint Edition 2015,Vol 2 Chapter 67, Purva khanda, chapter 6/202.

28. Vriddha Vagbhata, Ashtanga Samgraha with commentary by Prof.K.R.Srikantha Murthy, Chowkhamba Orientalia 2005, (A.S.Su.17/16)

29. Charak Samhita - Hindi Translation by Brhamananda Tripathi, Chaukhambha Bharati Academy Varanasi2007, Sutrasthana Chapter 26, verse 61-62.

\section{Source of Support: Nil \\ Conflict of Interest: None Declared}

How to cite this URL: Rashmi Choudhary et al: A Review On Role Of Ksharagad In Allergic Skin Diseases W.S.R. To Dushivisha Janya Twak Vikar. International Ayurvedic Medical Journal \{online\} 2020 \{cited November, 2020\} Available from: http://www.iami.in/posts/images/upload/5089 5095.pdf 